\title{
Takikardia QRS Lebar: Apa Mekanismenya?
}

\author{
Yoga Yuniadi
}

\section{Kasus}

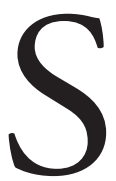

eorang pria, 60 tahun sedang dirawat di ruang rawat intensif pasca operasi bedah pintas koroner (BPAK) dengan episode takikardia QRS lebar berulang. Pasien masih dalam keadaan terintubasi dan mendapat obat-obat vasokonstriktor/inotropik. Sebelum operasi BPAK irama jantung irama sinus normal, tetapi pasca BPAK mengalami fibrilasi atrium. Terjadi penurunan lebih lanjut tekanan darah pada saat takikardia dengan QRS lebar. Pemberian amiodarone drip tidak dapat ditoleransi karena menyebabkan tekanan darah turun, sehingga diberikan xylocard drip.

Apakah mekanisme takikardia QRS lebar? Apakah xylocard obat yang tepat?

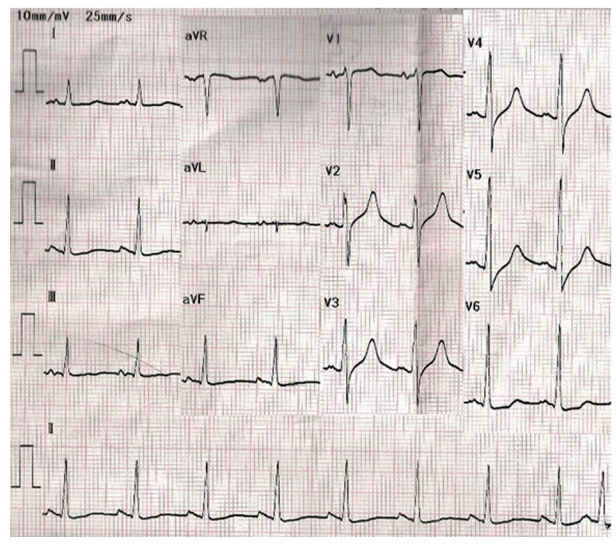

\section{Alamat Korespondensi}

Dr. dr. Yoga Yuniadi, SpJP. Divisi Aritmia, Departemen Kardiologi dan Kedokteran Vaskular, FKUI dan Pusat Jantung Nasional Harapan Kita, Jakarta. E-mail: yogay136@gmail.com
Perhatikan bahwa pada saat irama sinus QRS sempit, sebagaimana juga pada saat FA respon ventrikel normal.

Pada saat takikardia QRS lebar terlihat sebagai gambaran blok cabang berkas kiri (left bundle branch block=LBBB). Secara sepintas EKG ini seperti menunjukkan sebuat takikardia ventrikel (VT), tetapi perhatikan sadapan II panjang. Jelas terlihat bahwa takikardia QRS lebar ini irregular yang bertentangan dengan suatu sirkuit VT yang akan menyebabkan takikardia yang regular. Takikardia QRS lebar irregular hanya ditemui pada FA dengan aberansi, FA dengan preeksitasi, FA dengan preexisting BBB atau suatu VT polimorfik. Preexisting BBB ataupun preeksitasi jelas tidak ada pada pasien ini, sedangkan polimorfik VT juga tidak mungkin karena ketika terjadi ketidakteraturan laju

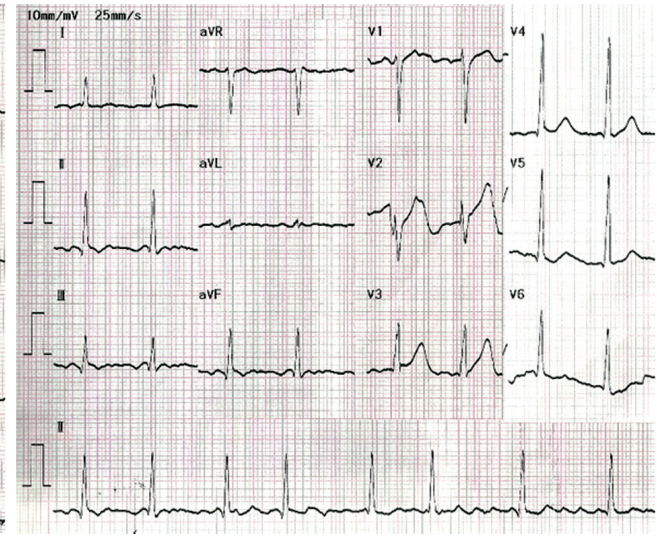

QRS, morfologi QRS sama dengan QRS pada segmen yang lebih teratur. Dengan demikian hanya suatu FA dengan aberansi yang mungkin pada pasien ini. 


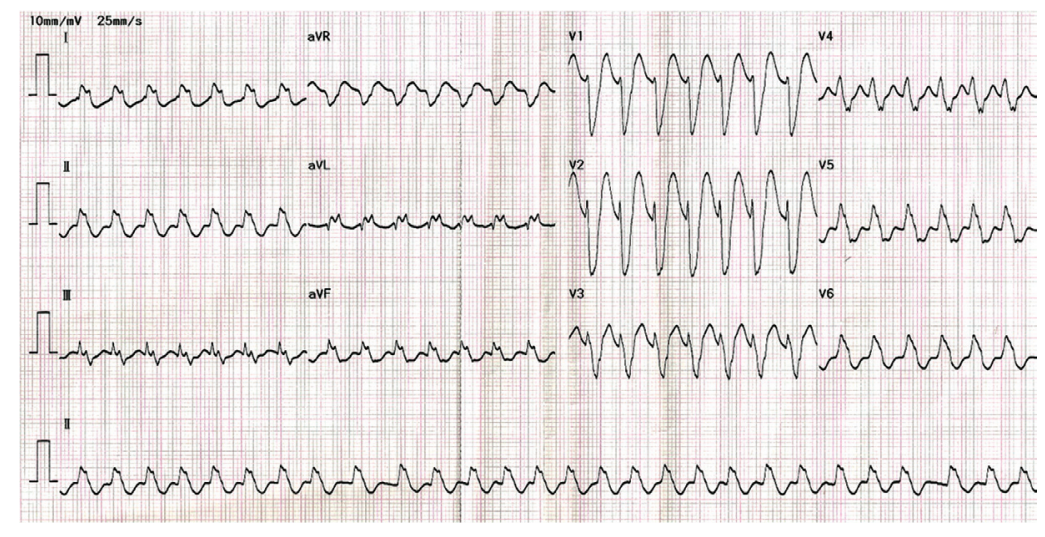

Masa refrakter jaringan jantung terbagi menjadi masa refrakter absolut dan masa refrakter relatif. Pada masa refrakter absolut, aksi potensial yang baru tidak dapat terjadi. Pada masa refrakter relatif sebuah aksi potensial baru masih mungkin terjadi yaitu bila terdapat stimulus yang lebih kuat. Konduksi aberan terjadi pada saat masa refrakter relatif. Panjang pendek masa refrakter dipengaruhi oleh laju jantung, karena durasi aksi potensial tergantung pada interval RR yang mendahuluinya. Jika interval $R R$ yang mendahului pendek maka durasi aksi potensial pendek, sebaliknya bila interval RR yang mendahuluinya panjang maka durasi aksi potensial memanjang. Maka jika terjadi interval RR pendek setelah suatu interval $R R$ yang panjang maka jaringan yang akan dilalui impuls memiliki masa refrakter yang panjang sehingga mungkin masih dalam keadaan masa refrakter absolut atau relatif sehingga tidak dapat dilalui impuls tersebut. Dalam hal impuls akan melalui cabang berkas kanan dan kiri dari berkas His maka karena perbedaan masa refrakter cabang kedua berkas tersebut, impuls hanya akan lewat melalui cabang berkas yang sudah pulih dari masa refrakter dan mengalami hambatan di cabang berkas yang masih dalam masa refrakter. Hal ini menghasilkan konduksi aberansi. ${ }^{1} \quad$ Aberansi terjadi karena perbedaan masa refrakter relatif antara berkas cabang kiri dan kanan. Pada umumnya berkas cabang kanan memiliki masa refrakter relatif yang lebih panjang. Oleh karena itu aberansi umumnya memiliki morfologi RBBB. Sebuah publikasi lama menunjukkan bahwa aberansi tipe LBBB hanya terjadi pada maksimal $15-30 \%$ kasus. $^{2}$

\section{Daftar Pustaka}

1. Neiger JS, Trohman RG. Differential diagnosis of tachycardia with a typical left bundle branch block morphology. World J Cardiol. 2011; 3: 127-34.

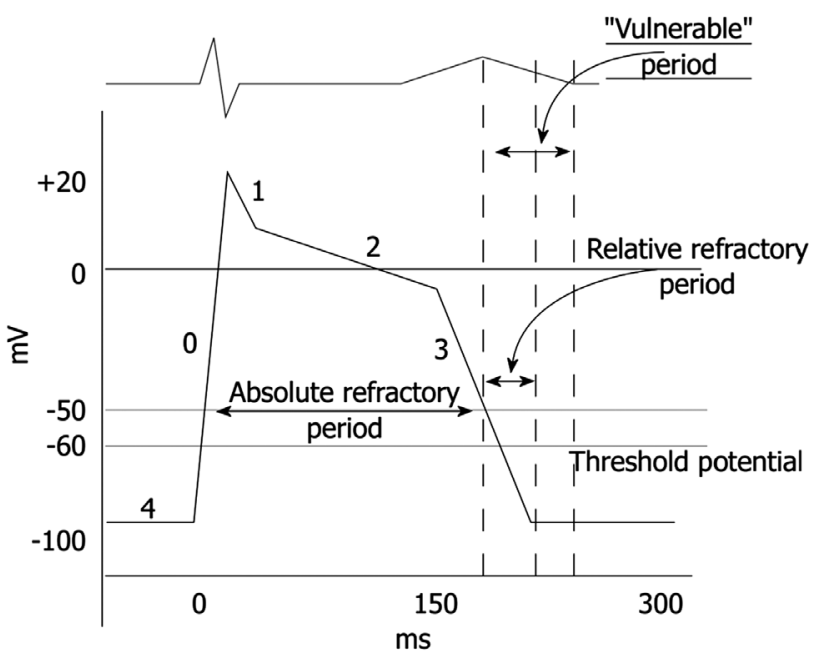

Gambar 1. Aksi potensial dari system His-Purkinje. Bila potensial ini berasal dari cabang berkas kiri, impuls yang dating pada masa refrakter absolut tidak akan diteruskan. Dengan demikian potensial yang baru tidak akan terjadi sehingga impuls hanya akan berjalan melalui cabang berkas kanan dan menghasilkan gambaran blok cabang berkas kiri (left bundle branch block, LBBB). Dikutip dari kepustakaan no. 3

2. Sandler LA, Marriott HJ .The Differential Morphology of Anomalous Ventricular Complexes of RBBB-Type in Lead V; Ventricular Ectopy Versus Aberration.Circulation. 1965; 31:551-6.

3. Potger KC. Vulnerable period of cardiac cycle. 2011. Last accessed Mar 2, 2016. Available from: URL: http://www.anzcp. org/CCP/Biomedical electronics/biomed/Vulnerable period. htm 